\begin{tabular}{|c|c|c|}
\hline \multirow{4}{*}{$\begin{array}{r}\text { Case Reports in } \\
\text { Gastroenterology }\end{array}$} & \multirow{2}{*}{\multicolumn{2}{|c|}{ Case Rep Gastroenterol 2019;13:539-543 }} \\
\hline & & \\
\hline & $\begin{array}{l}\text { DOI: 10.1159/000504433 } \\
\text { Published online: December 19, } 2019\end{array}$ & $\begin{array}{l}\text { ( } 2019 \text { The Author(s) } \\
\text { Published by S. Karger AG, Basel } \\
\text { www.karger.com/crg }\end{array}$ \\
\hline & $\begin{array}{l}\text { This article is licensed under the } \mathrm{Cr} \\
\text { International License (CC BY-NC) (ht } \\
\text { Usage and distribution for commercial }\end{array}$ & $\begin{array}{l}\text { nons Attribution-NonCommercial } 4.0 \\
\text { ger.com/Services/OpenAccessLicense). } \\
\text { uires written permission. }\end{array}$ \\
\hline
\end{tabular}

\title{
A Progressive Huge Accessory Spleen in the Greater Omentum
}

\author{
Hirokazu Matsuzawa Shinya Munakata Hirotaka Momose \\ Yuki Tsuchiya Shun Ishiyama Hirohiko Kamiyama Makoto Takahashi \\ Kazuhiro Sakamoto \\ Department of Coloproctological Surgery, Faculty of Medicine, Juntendo University, \\ Tokyo, Japan
}

\section{Keywords}

Accessory spleen $\cdot$ Laparoscopic resection $\cdot$ Greater omentum

\begin{abstract}
Huge accessory spleen (AS) is a rare condition difficult to diagnose. We recently treated a Japanese woman with a progressive huge AS. She had a history of aortic valve replacement for aortic stenosis 1 month prior. At that time, a $4-\mathrm{cm}$ AS had been detected by the preoperative computed tomography (CT). This mass was a progressive tumor which grew to $7 \mathrm{~cm}$ over the course of 3 months. Thus, we performed surgery with a preoperative diagnosis of huge AS by $\mathrm{CT}$ and positron emission tomography. A laparoscopic resection was performed considering the risk of torsion, spontaneous rupture, or hemorrhage. The final pathological diagnosis was AS. This is the first reported case in the English literature of progressive AS with no symptoms at the initial presentation that was treated with laparoscopic resection.
\end{abstract}

(C) 2019 The Author(s)

Published by S. Karger AG, Basel

\section{Introduction}

Huge accessory spleen (AS) is a rare condition difficult to diagnose, particularly if the patient presents no history of exposure to carcinogens. ASs may be formed during embryonic development when some of the cells from the developing spleen are deposited along the path 
from the midline, where the spleen forms, over to its final location on the left side of the abdomen [1]. The occurrence of ASs has been variously reported in $10-30 \%$ of the population [2, 3]. They have been found at sites from the diaphragm to the scrotum, but the vast majority are located near the main organ, usually in the splenic hilum or along the splenic vessels or associated ligaments [4]. Although their size varies, most ASs remain small nodules. In some cases, residual splenic tissue from a splenectomy undergoes compensatory enlargement [5].

Here, we report a rare case of progressive AS in a Japanese female patient, which was successfully diagnosed preoperatively. Surgery was subsequently performed, using a laparoscopic approach.

\section{Case Presentation}

A 47-year-old woman was referred to us by a cardiac surgeon after detection of a large abdominal mass. Clinically, the patient presented with no symptoms. She had a history of aortic valve replacement for aortic valve stenosis 1 month prior. At that time, a 4-cm AS had been detected by the preoperative computed tomography (CT). There was no associated weight loss or fever. On physical examination, the abdomen was soft; no rebound tenderness or palpable mass in the abdomen could be detected. The laboratory findings revealed no abnormalities except for a slightly elevated brain natriuretic peptide level of $68.7 \mathrm{mg} / \mathrm{dL}$ and a low hemoglobin blood level of $10.8 \mathrm{mg} / \mathrm{dL}$. The tumor marker levels were also within normal ranges: carcinoembryonic antigen at $0.7 \mathrm{ng} / \mathrm{mL}$ and carbohydrate antigen $19-9$ at $10 \mathrm{U} / \mathrm{mL}$.

The patient's chest X-ray showed nonspecific findings. Abdominal CT showed a huge tumor, about $7 \mathrm{~cm}$ in maximum diameter over the course of 3 months, that was well marginated, irregular, and homogeneously enhanced to a similar degree as the splenic parenchyma (Fig. 1a). On abdominal MRI, the tumor exhibited a low-intensity signal on the T1-weighted image and a high-intensity signal on the T2-weighted image. Positron emission tomography (PET)/CT showed diffuse uptake in a contrast-enhancing lesion in the left abdomen with the same physiologic uptake as the adjacent spleen (Fig. 1b). Subsequently, both esophagogastroduodenoscopy (EGD) and colonoscopy were performed. The EGD showed chronic gastritis. The colonoscopy revealed that there was no undue pressure on the descending colon. But, oral double balloon enteroscopy revealed that the jejunum at $20 \mathrm{~cm}$ from the Treitz ligament had pressure from the abdominal mass. Based on these findings, we performed surgery with a preoperative diagnosis of huge AS.

The patient underwent laparoscopic resection under general anesthesia. She was positioned in the supine position and a three-port method was employed. Three operation ports were used: a $12-\mathrm{mm}$ umbilical camera port, a $12-\mathrm{mm}$ working port in the lower right abdomen, and a 5-mm working port in the upper right abdomen. The spleen itself was normal. A huge, well-marginated mass was observed in the greater omentum on the left side. The mass was fed by a vascular pedicle from the left gastroepiploic artery. The tumor was dark red, elastic, soft, and separate from the small intestine (Fig. 2). The feeding artery was dissociated and ligated with a Laparo-Clip to diminish the risk of severe hemorrhage. Care was taken to avoid fragmentation and further implantation of the splenic tissue by extending the skin incision to $7 \mathrm{~cm}$. The excised tumor measured $7.0 \times 6.0 \times 6.0 \mathrm{~cm}$ (Fig. 3a). Microscopically, lymphoid follicles and splenic pulp were found, and these had the appearance of normal splenic tissue (Fig. 3b). The final pathological diagnosis was AS. The patient had an uneventful postoperative course and was discharged 3 days after the operation. 


\section{Discussion}

We reported a nonsymptomatic 7-cm progressive AS. Of their 311 cases of AS, Halpert and Gyorkey [2] reported that the minimum AS was $0.2 \mathrm{~cm}$ and the maximum was $6 \mathrm{~cm}$, and that most cases were associated with leukemia and other hematological disorders.

It is rare that a 7-cm AS was resected without an underlying hematologic disease such as leukemia, malignant lymphoma, or idiopathic thrombocytopenic purpura, or postsplenectomy. However, recent papers have reported a $12 \times 38 \mathrm{~cm}$ huge AS and torsion of a $17-\mathrm{cm}-$ diameter AS [6, 7].

It has been pointed out that ASs occasionally become symptomatic because of torsion, spontaneous rupture, hemorrhage, and cyst formation $[8,9]$. Our case was a progressive AS, and we finally performed a resection. However, some cases have been difficult to diagnose preoperatively. Nishiguchi et al. [10] reported that imaging methods such as ultrasonography, $\mathrm{CT}$, and MRI do not show signals specific to an AS. They also reported that scintigraphy with Tc-99m phytate is the most useful method of evaluating an AS [10]. However, scintigraphy is difficult to perform immediately after the incidental detection of an abdominal mass. As for the feeding blood vessel, since this case originated from the gastroepiploic artery, we suspected an omental gastrointestinal stromal tumor preoperatively. Typically, ASs appear on CT scans as well-marginated, round masses and enhance homogeneously. PET/CT helped us to diagnose the mass preoperatively, due to its having the same uptake as the normal spleen.

In conclusion, we report a case of progressive AS. A laparoscopic accessory splenectomy was performed considering the risk of torsion, spontaneous rupture, or hemorrhage.

\section{Acknowledgements}

We would like to thank Greta Davis for revising this article, including English expressions.

\section{Statement of Ethics}

This study was performed in accordance with the ethical standards of the Committee on Human Experimentation of our institution. Patient consent was obtained for describing his clinical course in a case report.

\section{Disclosure Statement}

The authors declare no conflict of interest. The authors declare that they have no competing interests.

\section{Funding Sources}

The authors declare that this work was not supported by any grants or funding. 


\section{Author Contributions}

H. Matsuzawa, H. Momose, Y. Tsuchiya, S. Ishiyama, H. Kamiyama, and M. Takahashi: data acquisition. S. Munakata: drafting of the manuscript. S. Munakata and K. Sakamoto: critical revision of the manuscript.

\section{References}

1 Unver Dogan N, Uysal II, Demirci S, Dogan KH, Kolcu G. Accessory spleens at autopsy. Clin Anat. 2011 Sep;24(6):757-62.

2 Halpert B, Gyorkey F. Lesions observed in accessory spleens of 311 patients. Am J Clin Pathol. 1959 Aug;32(2):165-8.

3 Gardikis S, Pitiakoudis M, Sigalas I, Theocharous E, Simopoulos C. Infarction of an accessory spleen presenting as acute abdomen in a neonate. Eur J Pediatr Surg. 2005 Jun;15(3):203-5.

4 Schwartz SI, Adams JT, Bauman AW. Splenectomy for hematologic disorders. Curr Probl Surg. 1971 May:157.

5 Beahrs JR Jr, Stephens DH. Enlarged accessory spleens: CT appearance in postsplenectomy patients. AJR Am J Roentgenol. 1980 Sep;135(3):483-6.

6 Zhang C, Zhang XF. Accessory spleen in the greater omentum. Am J Surg. 2011 Sep;202(3):e28-30.

7 Bard V, Goldberg N, Kashtan H. Torsion of a huge accessory spleen in a 20-year-old patient. Int J Surg Case Rep. 2014;5(2):67-9.

8 Wacha M, Danis J, Wayand W. Laparoscopic resection of an accessory spleen in a patient with chronic lower abdominal pain. Surg Endosc. 2002 Aug;16(8):1242-3.

9 Vural M, Kacar S, Koșar U, Altin L. Symptomatic wandering accessory spleen in the pelvis: sonographic findings. J Clin Ultrasound. 1999 Nov-Dec;27(9):534-6.

10 Nishiguchi S, Habu D, Ishizu H, Iwata Y, Tatsumi N, Enomoto M, et al. Accessory spleen in the pelvis diagnosed by Tc-99m phytate scintigraphy. Ann Nucl Med. 2001 Jun;15(3):263-5.
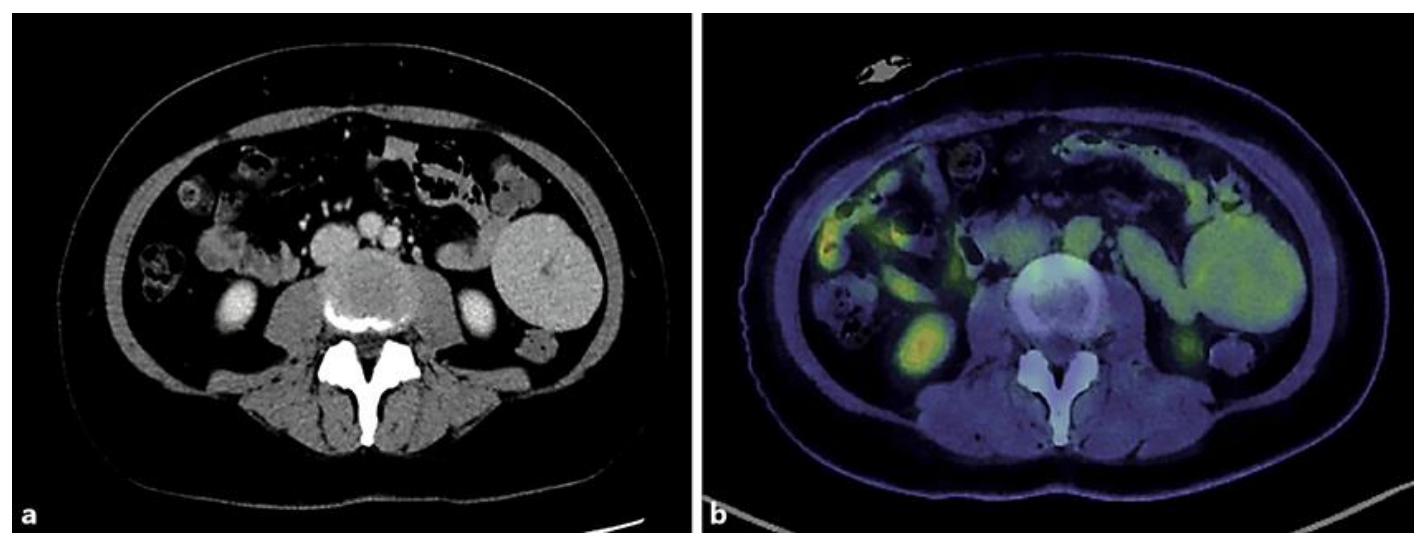

Fig. 1. a Computed tomography showed a 7-cm well-marginated, irregular mass enhanced homogeneously. b Positron emission tomography/computed tomography imaging showed normal physiologic uptake of the abdominal mass. 


\section{Case Reports in Gastroenterology}

Case Rep Gastroenterol 2019;13:539-543

DOI: $10.1159 / 000504433$

(c) 2019 The Author(s). Published by S. Karger AG, Basel www.karger.com/crg

Matsuzawa et al.: A Progressive Huge Accessory Spleen in the Greater Omentum

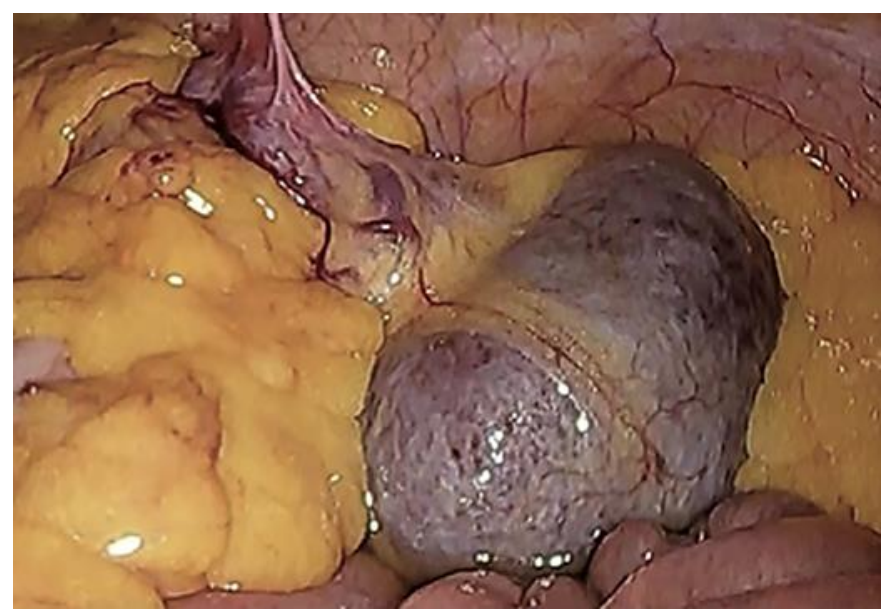

Fig. 2. Laparoscopic observation revealed the huge accessory spleen in the left abdomen. The color and elasticity were similar to those of the normal spleen.
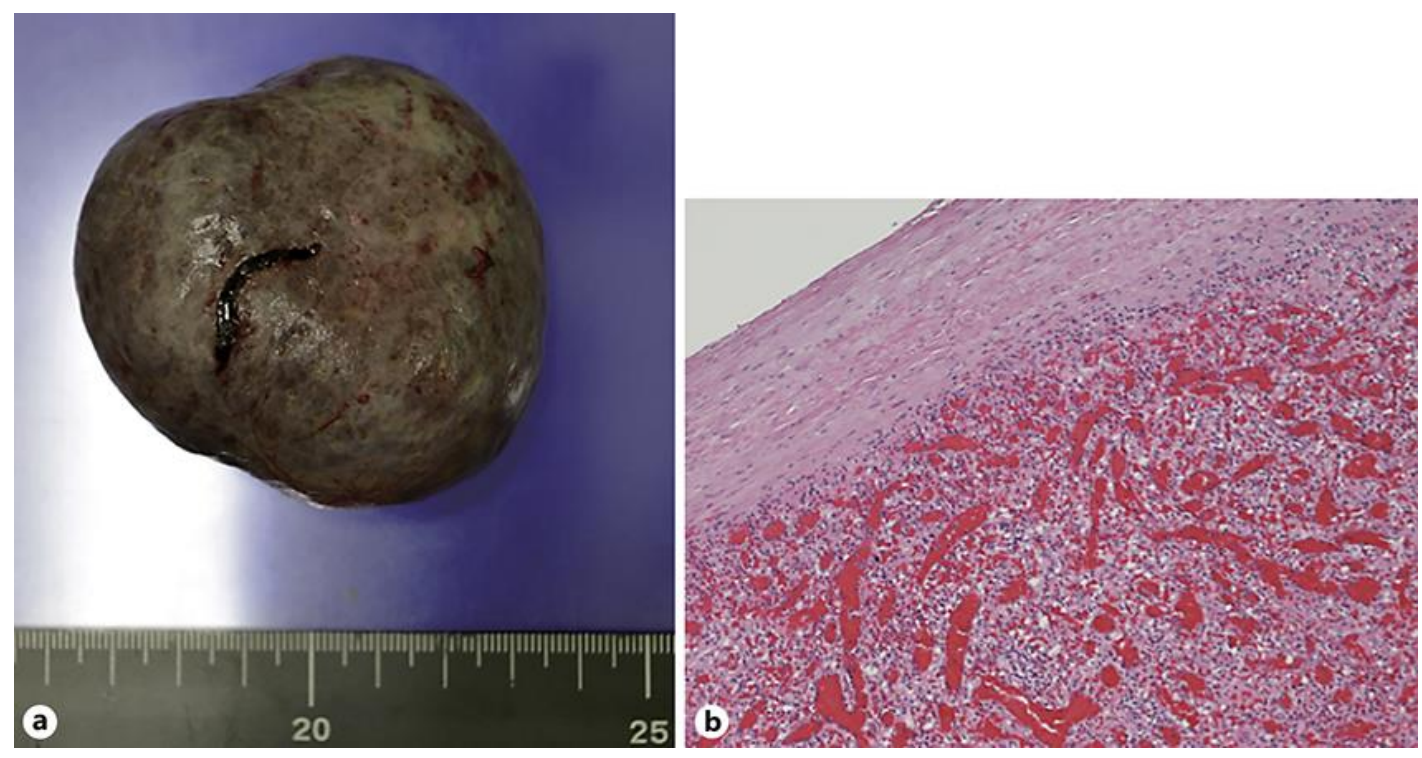

Fig. 3. a Macroscopic view of the surgically resected specimen measuring $7 \times 6 \times 6 \mathrm{~cm}$. b Microscopically, splenic pulp was found and had the appearance of normal splenic tissue. Magnification, $\times 40$. 